\title{
ARTICLE
}

Received 6 Jul 2016 | Accepted 2 Nov 2016 | Published 29 Nov 2016

\section{Integrity: the virtue of compromise}

\author{
Jeremy Schwartz ${ }^{1}$
}

\begin{abstract}
In this article, I develop a novel interpretation of integrity that I believe ought to be of special interest to business ethicists. According to a traditional understanding, integrity is the virtue of holding fast to one's principles in the face of temptations. Against this, I suggest that integrity is the virtue that governs rather than forbids compromise. In other words, integrity does not just forbid compromise; it sometimes demands it. This virtue will sound paradoxical to some, and I spend much of the essay arguing for its plausibility and locating it within the larger philosophical tradition. In the second half of the essay, I try to connect this virtue to the essential aims of business as understood by shareholder theorists. If my argument is correct, it may explain why integrity is of such central concern for business ethicists. This article is published as part of a collection on integrity and its counterfeits.
\end{abstract}

\footnotetext{
${ }^{1}$ Texas Tech, Lubbock, TX, USA Correspondence: (email: jeremy.m.schwartz@ttu.edu)
} 
O ne of the few things accepted by most theorists who write about integrity is that it is incompatible with compromising one's morals. Integrity, it is thought, involves "sticking to one's principles ... even in the face of temptation" (McFall, 1987: 7); (Halfon, 1989: 29; Worden, 2003; Audi and Murphy, 2006: 4). In this article, I would like to challenge this common opinion by arguing that integrity involves being open to moral compromise. Although some theorists have acknowledged the necessity of compromise when one is trying to come to a shared policy with equally principled but disagreeing parties, I will argue that even self-interest can sometimes justify moral compromise. Since there are many senses of integrity in the literature, I will call the sense of integrity under discussion compromise integrity and define it to be the virtue that governs rather than forbids moral compromise.

As is often noted, the virtue of integrity suffers from an unusual amount of controversy regarding its core meaning (Becker, 1998; Parry and Proctor-Thomson, 2002; Koehn, 2005; Palanski and Yammarino, 2007). While other virtues are certainly contested around their borders, few doubt that courage governs situations of danger and generosity situations of assistance. But with integrity, there seems to be little agreement even about its core meaning. Is it just a kind of honesty (Trevino et al., 2000: 130 )? Is it consistency between deeds and actions (Simons, 2002)? Is it a commitment to one's principles (McFall, 1987)? Or commitment to good principles (Becker, 1998: 157)? Or perhaps, integrity is a matter of wholeness (McFall, 1987; Koehn, 2005; Pianalto, 2012). ${ }^{1}$ Faced with this confusing array of alternatives, some have sought an underlying unity behind all of these conceptions, while others have denied the existence of such a unity and have argued that many appeals to integrity would be better served by appealing to "integrity as" where a term is inserted after the "as" that specifies the sense of integrity under discussion (Audi and Murphy, 2006: 16). Most have agreed that some sort of terminological clarity is in order. These confusions about the core meaning show that discussions of integrity do well to specify the kind of integrity that is under discussion. Although my specification of compromise integrity goes partway to satisfying this demand, the present discussion seeks not just to reference a pre-existing understanding of integrity but also to argue that one sense of integrity has gone missing from the standard debate. In such a case of revision to the common understanding, one must also explain how the sense of integrity under discussion relates to more traditional senses.

My defense of compromise integrity will occur in two stages. Compromise integrity, I suspect, will sound paradoxical to some and downright immoral to others. In the first section of this article, I will try to allay these concerns by showing that there are intuitive cases where concerns of self-interest can reasonably outweigh concerns of duty, and I will locate this idea within a larger philosophical tradition. I will also relate compromise integrity to more traditional understandings of integrity. In the second section of this article, I will argue that compromise integrity ought to be of special concern to business ethicists. My hope is that this conception of integrity will more closely align with the moral vision of actual business practitioners-a vision that sometimes clashes with the moral vision of contemporary ethical theorists (Stark, 1993; Worden, 2003).

\section{Compromise}

Jane Austen opens up Sense and Sensibility with the tale of a dying promise made by John Dashwood to his father (Austen, 1811: Chapter 1). Dashwood promises his father to take care of Dashwoods's soon-to-be indigent half-sisters. Although he does not promise an exact amount, he immediately resolves to give

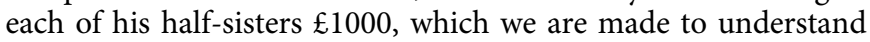

would be a modestly generous contribution. Once Dashwood's wife hears of this, she immediately sets to work on him. Playing on his greed and selfishness, she gradually talks him down from his original generous intentions to $£ 500$ each, then $£ 100$ per year, then $£ 50$ now and again, until finally they settle on giving his halfsisters next to nothing. Now most would agree that Dashwood displays a distinct lack of integrity and would agree that he lacks integrity because he has compromised his original moral intention. Inverting Halfon's (1989: 71) definition of uncompromising, we could say that someone compromises when they are willing to "modify their commitment or revise their principles or ideals without a good reason". Since Austen brilliantly relates the specious arguments that Mrs Dashwood uses on her husband, the reader is left with strong evidence that Dashwood's modifications are grounded in anything but good reasons. Combining these elements, we arrive at a preliminary understanding of integrity as an unwillingness to modify one's ideals for bad reasons.

There is an important debate about whether integrity requires that the ideals to which one adheres be good ideals or whether there is something admirable about sticking to any ideals whatsoever. Those who argue for the former, point out that the steadfast Nazi is hardly a picture of moral integrity. But even assuming that one's ideals are good, the preliminary definition of integrity as unwillingness to modify one's ideals for bad reasons is unhelpful. To be substantive, it needs to spell out what counts as a bad reason. While no account attempts to provide necessary and sufficient conditions, some content is provided by the near universal assumption that self-interest is a canonically bad reason. Thus, many commentators talk about facing temptation or suffering burdens in the name of one's principles (McFall, 1987; Halfon, 1989). The clear implication is that modifying one's commitments or revising one's principles or ideals because of self-interest is the kind of compromise that a person of integrity would avoid. It is this claim that I would like to challenge.

Others have acknowledged that integrity sometimes involves modifying one's principles or compromising one's values. Thus, Halfon (1989: 63) notes that changing one's mind when you think that you have been wrong is an instance of modifying one's principles that is consistent, even demanded by integrity. Goodstein (2000: 814) has argued that in situations of group decision and moral deadlock, compromise is required in order to reflect the fact that "such positions may be based on moral principles about which people may reasonably disagree". ${ }^{2}$ But none of these compromises comes close to excusing departures based merely on appeals to self-interest. It is the latter, unexplored category, that I will investigate in this article.

Consider a variation of the "Heinz scenario" made famous by Kohlberg (1981: 12) in his theory of moral development. ${ }^{3}$ According to the original scenario, Heinz's wife will die unless Heinz steals some medicine to save her. But now imagine that it is Heinz himself who is sick, and he must steal medicine to save his own life. Let us suppose further that before this situation occurs, Heinz has endorsed the principle that it is wrong to steal medicine. Moreover, he has even endorsed the general principle that dire need does not justify the theft of another person's property. If, despite these declarations, Heinz steals the medicine, does Heinz show a lack of integrity in doing so? According to the canonical understanding of integrity, Heinz's case is no different from Dashwood's. Both of them have modified a principle in the name of self-interest. Since reasons of self-interest are always supposed to be bad reasons to change one's moral principles, each of them lacks integrity for the same reason.

I hope that this story reveals something decidedly wrong with the canonical understanding of integrity. Although both Dashwood and Heinz are indeed modifying their ideals for reasons that fall under the general heading of "self-interest", Heinz's 
reasons seem like they might be good reasons whereas Dashwood's reasons do not. I take it that this shows that reasons of self-interest come in varying degrees of persuasiveness and that they don't lose their effectiveness to the same degree when opposed to a moral command. Indeed, in the case of Heinz, we might even think that Heinz is reasonable to steal the medicine, and we might not think any worse of Heinz for doing it. But even if one only thinks that Heinz ought not to steal the medicine but that he is more justified than Dashwood, then one agrees that selfinterest can mitigate against moral principles. Compromise integrity attempts to develop this intuition.

Many will be tempted to resist my analysis of the Heinz dilemma. Instead, they will say that Heinz is actually acting for impersonal reasons. Heinz now sees that human life, including the right to necessary medicine, is more important than property rights. When Heinz faces this dilemma he learns that his original principle about theft requires a qualification. Heinz has come to accept the much more plausible principle that stealing is wrong except in cases where a human life is at stake. According to this objection, Heinz has not modified his principles because of selfinterest, but has been forced to learn a disinterested fact about the relative importance of human life and property rights.

Putting aside questions of whether Heinz's need does indeed justify his theft, Heinz might not accept this analysis of his own case. Perhaps, Heinz thinks that the world would be better off if people didn't feel free to steal from each other and may feel that stealing even for a chance to save your own life sets a dangerous precedent. He just thinks that the rule doesn't apply in his situation. Kohlberg (1981: 13) reports that although 75\% surveyed said that it would be wrong to steal, most reported that they might do it. In other words, most people think that it is wrong but they would do it anyway. Now, there is a certainly an air of paradox here. If Heinz thinks that he has good reason to make an exception in his case doesn't he also think that everyone else has good reason to make an exception in similar cases? Doesn't this mean that Heinz implicitly endorses a principle that everyone ought to steal medicine when her life is on the line? If Heinz thinks it is reasonable for him to make an exception, perhaps he must endorse a universal principle that allows everyone to make exceptions in similar cases.

Although philosopher's have been tempted by this sort of argument, most agree that it is fallacious (Williams, 1985; Allison, 1991). ${ }^{4}$ To explain this point, philosophers have noted that a rational egoist would have no reason to accept the above argument. Since a rational egoist holds that only egoistic considerations have any weight, she could simply deny that appeals to universality have any weight with her:

Such an egoist could perfectly well affirm the universality of applicability of his governing principle, since he could endorse the claim that it would be reasonable for every other agent to act on it. Nevertheless, the egoist could hardly claim that the universal adoption of his principle would be universally beneficial and, therefore, rationally desirable. (Allison, 1991: 5).

The egoist thinks that (1) it is in her own interest to make an exception, (2) it is in the interest of each to make an exception, and (3) it is in her own interest that no one else makes the exception. Since only her interests count as reasons for her, it is reasonable to make an exception for herself but not reasonable that everyone make an exception for themselves. Quoting the egoist Max Stirner, Williams (1985: 62) makes the point this way, "The tiger that assails me is in the right, and I who strike him down am also in the right. I defend against him not my right, but myself'. When Heinz uses self-interest to trump a moral consideration, he may be acting immorally, but he is not acting unreasonably.

Although I have made the point by appealing to the unbridled egoist, Heinz need be no such creature. Heinz may give some weight to moral reasons but think that, on occasion, his selfinterest trumps moral concerns. Although not many have defended such a view, several philosophers have noted its possibility. Famously, the great utilitarian philosopher Henry Sidgwick concludes his classic defense of utilitarianism with such a concession. Sidgwick takes himself to have established that utilitarian considerations have weight, and he personally believes that they ought to be given the greatest weight, but he acknowledges that someone might coherently deny this. Perhaps, egoistic and utilitarian reasons co-exist in an uneasy tension. When we try to assess our actions strictly in terms of their reasonability, we find that it is reasonable both to give the preferences of others equal weight, and it is reasonable to give our own preferences special weight. Adjudicating between them is not something that can be settled by reason.

Sidgwick hastens to add that the situation is more of a theoretical than a practical difficulty. Most of the time, and more often than we think, the action that is in the interest of all is also the action that is in our best interest. Usually, therefore, there is only one reasonable thing to do. Sometimes, however, what is required by self-interest and what is required by duty conflict, and in such cases, Sidgwick thinks that reason cannot resolve the conflict:

But in the rarer cases of a recognized conflict between selfinterest and duty, practical reason, being divided against itself would cease to be a motive on either side; the conflict would have to be decided by the comparative preponderance of one or other of two groups of non-rational impulses. (Sidgwick, 1907: 508)

Self-interest and duty are each atomic and non-derived reasons. There is no deeper or higher considerations in virtue of which the claims of each can be adjudicated. Since reason has no ability to weigh the two considerations in terms of a third consideration, it simply throws up its hands and lets some other faculty decide. At one time, Sidgwick referred to this as the "dualism of practical reason," and under this name, it continues to draw serious attention from philosophers. But if reason is dualistic in this sense, then Heinz's decision to steal the medicine is neither incoherent nor brutally egoistic. His decision can be justified by his conviction that egoistic reasons trump duty in some cases.

Integrity theorists have mostly agreed that integrity involves not changing one's commitments or ideals for bad reasons. I have agreed with this consensus but noted that a great deal depends on what counts as a bad reason. Where I depart from typical integrity theorists is in their further assumption that sacrificing one's interest is always a bad motive for changing one's commitments. Dualism about practical reason directly challenges this assumption by allowing that self-interest and duty may sometimes be weighed against each other. If Heinz alters his decisions for good, albeit selfish, reasons then his change would not reflect a lack of integrity.

Integrity theorists have often noted that etymologically "integrity" means wholeness. According to these theorists, the virtue of integrity has to do with a sort of psychic integration (Audi and Murphy, 2006: 9). A person of integrity is not divided within herself whereas those who lack integrity express some sort of psychic (or practical) conflict (Pianalto, 2012). Hypocrites and weak-willed people like John Dashwood try to internalize conflicting commitments. Dashwood's behaviour reflects an 
inability to fully internalize either the principle of noble generosity nor the principle of selfish stinginess. That he originally formed the intention to give generously reflects his commitments to the former. That he waivered reflects his commitment to the latter. But can't such a criticism be leveled at Heinz? After all, Heinz is torn between two different kinds of reasons, and he has no principled way of reconciling these duelling commitments. From the perspective of psychic unity, Heinz seems to swing between duty and self-interest, and therefore to lack the kind of unity that these integrity theorists are pointing to.

This is an important criticism, and I think resolving this criticism holds the key to understanding integrity as the virtue that governs compromise. My suggestion here is that one of the functions of a virtue is to provide unity and integration that is not based on a principle. Virtue theory has taught us that for many spheres of concern, there is no decision procedure for solving moral problems (Hursthouse, 1999; Annas, 2004). The moral rules that do exist are subject to infinite qualifications and adjustments so that arriving at the correct result depends as much on judgment and discernment as it does on starting out with the correct rule. When does courage cross into foolhardiness? When does caution cross into cowardice? There are no rules that can help us decide. Instead, we must depend upon the properly trained discernment or judgment of virtuous agents. These virtuous agents do not follow rules in coming to their decisions, or at least they follow no rules that can be codified and followed by the non-virtuous. Instead, their judgment and discernment allow them to hit the mark, and their judgment and discernment are a product of their virtue. Courage crosses into foolhardiness at the exact moment that the courageous person decides that the danger is not worth the risk.

Notice, however, that one of the roles that the virtue provides is that of unifying a character that otherwise would seem disparate. Courage provides a good example. Caution and safety pull us in one direction. Boldness and advantage pull us in another. If wholeness could only be attained by endorsing a super-principle that comprehended each of these considerations and adjudicated between the concerns of each (like, say, the principle of utilitarianism), then a failure to find such a principle leads immediately to a lack of wholeness. Virtue theory can be seen as responding to this challenge by proposing that the virtue itself explains the unity. In one situation, the courageous person decides the danger is not worth the risk. In another situation, similar but not identical to the first, the courageous person decides that it is worth the risk. No previously applied principle fully explains the difference between the two. Nevertheless, the actions are not just random fluctuations between competing considerations. Instead, the unity is explained by the virtue itself. Possessing the virtue not only allows the agent to discern what actions are courageous but also allows us to see an underlying unity behind the courageous person's decisions. One of the insights of virtue theory, therefore, is that a domain that contains competing considerations that appear incapable of principled resolution can attain unity by means of a virtue that governs this domain.

Return to Sidgwick's concerns about the dualism of practical reason. Sidgwick worried that if we accepted both egoistic and utilitarian reasons, practical reason would be unable to adjudicate between them. The picture of someone deciding first in favour of herself and then in favour of impersonal happiness seems like a textbook case of split personality. The insight from virtue theory, however, suggests another possibility. If there is a virtue that governs such decisions between self-interest and duty, then wholeness can be achieved after all. The difference between Heinz and Dashwood is not explained by the application of a correct principle that can distinguish all such cases, but rather by the discernment of a virtuous agent. ${ }^{5}$ A virtuous agent would refuse to be influenced by prudential appeals after she has promised her father to take care of her half-sisters, but a virtuous agent might very well be influenced by appeals to prudence when she is deciding to steal in order to give herself a shot at surviving. Compromise integrity, I am suggesting, is the name of such a virtue that adjudicates between self-interest and virtue.

This analysis might seem counter-intuitive. Even if we accept that Heinz was in some sense justified, surely, it goes against common usage to point to him as a person of integrity. I share this intuition, of course, but I think that compromise integrity is less revisionist than it might, at first appear. Consider its relationship to those who hold that integrity is a matter of not changing one's principles in the face of temptation. If my account of compromise integrity is correct, then these many contemporary accounts would have latched on to a partial truth. They are right in pointing out that the most common vice in this domain is special pleading. Stories like those of Dashwood are the norm-people allow self-interest to overshadow their commitments far too easily and slip into one of the vices associated with compromise integrity. But, if we think that Heinz is correct to steal his medicine, then there might be a less common temptation on the other side. Someone who unreasonably held onto her principles even unto death when her death was not demanded would offend against compromise integrity on the other side. Traditional understandings of integrity may be right to emphasize the vice of too-easily changing one's principles because of selfinterest, but they are wrong to assume that this common vice correctly captures the whole range of vices associated with integrity.

Compromise integrity matches well with traditional understandings of integrity that relate interest to its etymological origins of wholeness. As I have explained above, a virtue like compromise integrity is necessary to explain how someone torn between the competing considerations of duty and self-interest can avoid a psychic split. Compromise integrity also matches with those who have held that integrity is a matter of matching words and deeds, so called behavioural integrity (Simons, 2002). The ability to follow through on one's professed principles is a crucial part of holding fast to one's ideals. Compromise integrity just adds that sometimes even professed principles must be abandoned and that a virtue is required to decide when these rare exceptions are warranted. Finally, even those who have identified integrity with the whole of virtue have been partly right. After all, compromise integrity has the whole of virtue as its object. It decides when, if ever, it is appropriate to abandon virtue for the sake of self-interest. Someone who does not have this virtue will have none of the others. ${ }^{6}$

\section{Compromise in business}

In the previous section, I hope to have established that there is conceptual space to talk about a virtue that governs the competing considerations of self-interest and duty, and I have outlined its relationship to more traditional understandings of integrity. In this section, I would like to argue that compromise integrity is of special importance to business ethicists. This should come as no surprise. Integrity, as a whole, has long been of special interest to business ethicists in a way that it has not been to other ethical theorists (Audi and Murphy, 2006: 3-5). My account of compromise integrity would explain why this is so. The central thought here is that Heinz-type scenarios will be especially common for business managers because the aims of business have the effect of making conflicts between duty and self-interest especially stark. Obviously, this depends upon an understanding of the aims of business and the role of managers in advancing this aim. It is to this question that I first turn. ${ }^{7}$ 
The medical profession aims at health. The legal profession aims at upholding the law. But what does business as a profession aim at? This debate and the related debate about the nature of a corporation have long been central concerns of business ethicists. In the "corporate objective" debate, there are two main, but opposing traditions. ${ }^{8}$ According to shareholder theory ((Friedman, 1982; Sternberg, 1997; Sundaram and Inkpen, 2004b; Orlitzky, 2015), the purpose of a corporation is to maximize the value of the company for the sake of the shareholders. According to this theory, managers have a fiduciary relationship (Marcoux, 2003) to their shareholders. Since the interests of the shareholders is to maximize the value of the corporation, managers must, on pain of violating their fiduciary relationship, maximize ("without deception or dishonesty" (Friedman, 1982: 133)) the value of the corporation. Opposed to the shareholder theory is the stakeholder theory (Freeman, 1984; Donaldson and Preston, 1995; Lucas, 1998; Freeman et al., 2004). According to stakeholder theory, corporations are not just beholden to their shareholders but to everyone who has an interest in or is affected by the actions of the corporation. Thus, managers must take account not only of their shareholders but also their employees, their customers, suppliers, creditors, competitors, their community, perhaps even the environment and anyone else who "can affect or is affected by the achievement of the organization's objectives" (Freeman, 1984: 46). According to stakeholder theory, managers can consider the interests of their employees not just as a means to maximizing the value of their corporation but for their own sake. The debate between shareholder and stakeholder theorists shows no signs of abating and new arguments for each camp are continually being presented. Indeed, according to some, the ideological consensus has been swinging back and forth like a pendulum for the last 150 years (Sundaram and Inkpen, 2004a; Allen, 1992).

Resolving this complex debate is obviously beyond the scope of this article. However, I would like to take a stand on a related issue and consider the implications of this for the integrity debate. Stakeholder theorists (Lucas, 1998; Solomon, 1999; Venkataraman, 2002; Freeman et al., 2004) advert to the fact that business is fundamentally a cooperative enterprise. Although it is also competitive, business itself exists in order to create value for everyone involved not just those in the business. A particular cell-phone business may aim at profit, but cell-phone businesses in general exist because they satisfy a human need to communicate. It is only because they are helping attain this value that there are such things as cell-phones and therefore also cell-phone businesses. Just as law is in the business of upholding justice and medicine is in the business of human health, business is in the business of creating value and fulfilling human needs.

Shareholder theory takes a different approach. According to shareholder theory, businesses exist for the sake of profit. Consider, for example, the mission of a for-profit hospital (Worden, 2003: 32). While the medical mission of the hospital may be to promote the health of the community, the business mission of the hospital must be about profit. According to shareholder theorists, many organizations aim at the fulfillment of human needs (including charities, not-for-profit organizations, and social clubs), a business distinguishes itself by giving a return on investment (Vallance, 1995: 32). Once an endeavour is marked as a business, it is assumed that it aims for the increase of its own value. Shareholder theorists hasten to note that treating employees well, satisfying customers, and even being perceived as good citizens of the community are instrumentally valuable to this fundamental aim of the corporation. They differ from stakeholder theorists in assuming that these sound business practices are instrumentally justified rather than ends in themselves.

I believe progress can be made on this debate by drawing a distinction between the external and internal aims of a practice.
In “Two Concepts of Rules” (Rawls, 1955), Rawls (1955: 26 ) distinguishes between justifying something within a practice and justifying the practice itself. Baseball illustrates this point nicely. Like many sports, baseball aims at the enjoyment of the participants and spectators. That is why such practices exist. Nevertheless, there are rules that are internal to baseball that have nothing to do with the enjoyment of the spectators. According to this internal perspective, the aim of baseball is victory according to the prescribed rules not the enjoyment of the spectators even if baseball as a practice exists for the sake of the enjoyment of the spectators. Let us call the reason that baseball exists as a practice, an external aim and the reasons that are internal to baseball, internal aims.

There is a sense in which external aims are the supreme condition of internal aims. After all, internal aims can evolve and change and these changes are guided by the external aims. When people argue that an illegal-defense rule ought to be enacted to oppose the infield shift, they make arguments in terms of spectator enjoyment-the external aim of baseball-not arguments that appeal to existing rules of baseball. But even if these rules are, in one sense, ultimate, they are not always appropriately invoked. When appealing a call, one cannot invoke spectator enjoyment and hope to receive an ear. On the field, within the practice, the internal norms are the final authority.

It is important to emphasize something that Rawls only briefly touches on. Insofar, as the participants of a practice are genuinely engaged in the practice, they can be assumed to share the internal aims of the practice. Someone who cares not about winning but only about getting home as quickly as possible to catch a nap or cares only about achieving a certain score to win a bet is, in a real sense, not even playing the game of baseball. Indeed, there is also a sense in which someone who cares only about the enjoyment of the spectators but does not care about winning is not playing baseball either. Not only are one's actions interpreted within the practice, but also one's very motives are partly constituted by the decision to engage in the practice.

I would like to apply Rawls' internal-external distinction to the aim of business. Stakeholder theorists are surely right that business, as a practice, exists for its ability to satisfy human needs and create value. But, this speaks only to the external aim of business. It leaves open the question of what the constitutive norms internal to the practice of business are. If baseball understands itself to be about victory within the rules, how does business understand itself? Here is where the intuitions of the shareholder theorist come into their own. Shareholder theorists can insist that increasing the value of the business for the shareholders is exactly such an internal aim. Businesses practitioners must understand themselves as being "for profit" or they cease to be a business at all. Rawls' distinction makes it possible to suggest that stakeholder theorists are correct about the external aim of business and shareholder theorists are right about the internal aim.

Stakeholder theorists would surely be unsatisfied with this discussion. In particular, they would probably claim that value creation is not just an external aim of business but one of its internal aims as well. Instead of appealing to the practice of baseball where the internal and external aims are so different, perhaps, the stakeholder theorist could appeal to the practice of performance. Spectator enjoyment may not be an internal end of baseball, but it is surely both an external and an internal aim for magic shows. So too, the stakeholder theorist could argue creating value is part of both the external justification of business as well as the self-understanding of the practice of business (Solomon, 1999: 36-37).

While this is a plausible response, I think that this commits the stakeholder theorists to a very strong claim about the essential 
motives of business practitioners. I have argued above that a practitioner must share in the internal aims of the practice. I suspect a shareholder theorist would be perfectly comfortable saying that someone who participates in business without the aim of profit is plausibly regarded as not really participating in the practice of business at all. They are like a "baseball player" aiming at the enjoyment of the spectators. Would a stakeholder theorist be as comfortable making the same claim about a practitioner who fails to aim at creating value? Isn't it possible to participate in business just for profit? If so, then value creation is not part of the internal aim of business.

None of this is meant to be decisive, but I do think that it makes shareholder theory plausible, and for the duration of this article I will assume it. In particular, I assume that the external aim of business is indeed value creation, but a primary, if not the primary constituting internal aim of a business is increasing its own value (Keay, 2008: 678ff). One of the implications of this is that self-interest, or the interest of the company, can and should play a role in business ethics that it need not play in other fields of ethics. According to shareholder theory, the moral universe of business ethics is inhabited by entities whose constituting principle is the increase of its own value. Inside this entity, of course, are ordinary moral agents. But insofar as they are participating in the practice of business, they are participating in the entity's constitutive aim of increasing its own value. Managers are especially tasked with this aim and have a strict fiduciary responsibility to the growth of the entity (Friedman, 1982; Marcoux, 2003; Keay, 2008).

Consider how differently the typical moral agent is situated when not managing a business. I will consider a deontological agent, although a related story could be told for utilitarian and virtue-theoretic agents. According to deontologists, instead of having strict fiduciary responsibilities to the narrowly-understood interests of a third party, we mostly go about trying to maximize our preferences with morality setting the constraints within which this preference maximization must live (Nozick, 1974: 28-32). Moreover, our preferences themselves often contain a moral component. Most of us distinguish between the things that we happen to enjoy and the things we find important, and we are willing to sacrifice the things we want for the things we find important. Some deontologists have argued that morality is what allows us to distinguish the important from what we happen to like (Korsgaard, 1996: 91ff). Pulling these various strands together, we get the following deontological worldview. The world is populated by agents seeking what is important (as opposed to what is in their narrow interests) within the constraints of morality. Notice that self-interest is reconciled to morality in two fundamental ways. First, morality provides the boundaries in which self-interest is pursued, and second, morality, by means of the concept of "importance", is itself an element of how an agent views her self-interest.

I think that this difference in moral worldview leads a businessperson to experience more potent conflicts between duty and interest. The reasons for this are twofold. Notice first that as a fiduciary agent of another's interest, she is not free to simply forgo the interest of her company. Her commitment to the interest of her company is not alienable in the same way that our own interests are alienable. We have seen that adopting the internal aims of a practice is a condition for participating in the practice. This means that seeking the interest of the company is a condition for participating in the practice of business. A great enough departure from the interest of her company would threaten her very status as a businesswoman. In ordinary moral life, on the other hand, we are free not to pursue our own interests or the interests of another. When we do so, we are not jeopardizing our participation in the central aims of our life. ${ }^{9}$
The second reason that the claims of interest are so powerful in business is that interest is understood so narrowly. If the argument here is correct, the interest that a manager must preserve is very narrowly understood. As a contrast, it is useful here to consider the understanding of the self that views it as "socially responsive", that is, the self is construed broadly to include our relationship to others. We do well, at least in part, insofar as the things that we are part of do well. This understanding of the self serves to greatly mitigate the potential conflicts between duty and self-interest. But if our understanding of the aims of business is right, and if managers are fiduciary agents of these businesses, then they must understand the interest of their trustees very narrowly. One might even try to understand the rise of stakeholder theory as a response to the tension that managers feel in their fiduciary roles. One of the primary attractions of stakeholder theory is surely that "it tames the harsher aspects of capitalism" (Plender, 1997) and allows for managers to "incorporate moral values as a critical aspect of the strategic management process" (Keay, 2008: 675).

Compare here the role of manager to the role of parent. Both are fiduciary agents who must pursue the interest of their trustee if they are to fully inhabit their role. But the child's interests, unlike the company's interests are not narrowly understood. A parent could earnestly wish hardship on her child in order to increase the child's empathy. A parent could also wish that the child stand up for what she believes in even if the child has to pay dearly. In other words, parents are free to understand the interest of their children in a way that is wide enough to accommodate many moral concerns. But the businessperson is not so fortunate. If shareholder theorists are correct, then the business of business is profit. Not only is a manager a fiduciary agent, but she is a fiduciary agent for a trustee whose best interest must be very narrowly understood.

For these two reasons, the claims of interest are particularly powerful for managers of corporations. But this does not mean that the manager can simply ignore morality in the pursuit of the interest of her trustee. She doesn't leave her moral agency behind when she agrees to be a manager of a corporation. Instead, I submit that she is caught between two legitimate, conflicting and competing considerations. Her morality tells her not to pander to the racial prejudice of her clients, but she realizes that such a strategy may keep the company alive. If morality always trumped, her decision would be easy. If the interest of the company always trumped, her decision would be also be easy. The problem is that neither always trumps, and a decision has to be made. I submit that the business manager finds herself often in the position of Heinz. If my argument from Section 1 is correct, what is needed in order to make this decision is the virtue of compromise integrity - the ability to weigh the considerations of self-interest and duty and decide when an exception is warranted.

Compromise integrity is of special concern to business ethicists because businesspeople are often confronted by Heinz-type dilemmas. One strategy is more ruthless but will increase shareholder value. One employee is more loyal and more competent but doesn't have the connections of another employee. My argument in this section claims that such decisions are felt with particular force for fiduciary agents of an entity tasked with pursuing its own interest narrowly defined. For this reason, compromise integrity ought to be of special concern for business ethicists.

\section{Conclusion}

When one's principles encounter the messy world, they seldom remain untouched. Since principles are essential to who you are (McFall, 1987), being able to hold onto your principles in the face 
of these messy conflicts is essential. One way to hold on to them would be to simply never compromise. Someone who leaves life with the same principles that she went in with has certainly held on to herself. This solution, however, seems too rigid. Compromise integrity is what allows you to count as having held onto your principles even when circumstances have forced you to make an exception.

\section{Notes}

1 For a thorough review of literature with an emphasis on business ethics, see Palanski and Yammarino (2007). For a review of the integrity literature with an emphasis on ethical theory, see Cox et al. (2013).

2 See also Winslow and Winslow (1991).

3 I appeal here only to the scenario. I do not mean to reference Kohlberg's own understanding of the dilemma which, of course, has to do with moral developmental stages.

4 Even Kant, the philosopher most sympathetic to grounding morality in reason, did not think that believing that an exception was warranted in one's own case logically committed one to endorsing a universal principle allowing everyone to make an exception in such cases (Allison, 1991; Kerstein, 2002).

5 Unlike Goodstein (2000), therefore, I do not believe there is a way to specify, in advance which appeals to self-interest are never permitted. The boundaries are determined by what the virtuous person thinks.

6 Some might worry that compromise integrity is, by my accounts, not a virtue. After all, since it tells us when self-interest trumps virtue, it can't also be one of the virtues about which it adjudicates. I think this objection is right, but it only calls attention to the fact that integrity is a virtue that has other virtues as its object.

7 For an argument that business ethics and the corporate-objective debate have been too closely tied, see Orts and Strudler (2009).

8 For a persuasive alternative to the two main contenders, see Keay (2008). For Keay, managers must attempt to maximize not the profit of the shareholders but the longterm sustainability and value of the corporation itself.

9 Although for an argument that our important aims are indeed constitutive of agency and therefore, when threatened constitute a threat to integrity, see Smart and Williams (1973: 108).

\section{References}

Allen WT (1992) Our schizophrenic conception of the business corporation. Cardozo Law Review; 14 (1): 261-281.

Allison HE (1991) On a presumed gap in the derivation of the categorical imperative. Philosophical Topics; 19 (1): 1-15.

Annas J (2004) Being virtuous and doing the right thing. Proceedings of the Aristotelian Society; 78 (2): 61-75.

Audi R and Murphy PE (2006) The many faces of integrity. Business Ethics Quarterly; 16 (1): 3-21.

Austen J (1811) Sense and Sensibility. Palgrave Macmillan: New York.

Becker TE (1998) Integrity in organizations: Beyond honesty and conscientiousness. Management; 23 (1): 154-161.

Cox D, La Caze M and Levine M (2013) Integrity. In: Edward N Zalta (ed). The Stanford Encyclopedia of Philosophy, http://plato.stanford.edu/archives/ win2016/entries/integrity/.

Donaldson T and Preston LE (1995) The stakeholder theory of the corporation: Concepts, evidence, and implications. Management; 20 (1): 65-91.

Freeman RE (1984) Strategic Management: A stakeholder approach. Pitman Publishing: London.

Freeman RE, Wicks AC and Parmar B (2004) Stakeholder theory and "the corporate objective revisited". Organization Science; 15 (3): 364-369.

Friedman M (1982) Capitalism and Freedom, 2nd ed., The University of Chicago: Chicago.

Goodstein J (2000) Moral compromise and personal integrity: Exploring the ethical issues of deciding together in organizations. Business; 10 (4): 805-819.

Halfon MS (1989) Integrity: A Philosophical Inquiry. Temple University Press: Philadelphia, PA.

Hursthouse R (1999) On Virtue Ethics. Oxford University Press: New York.

Keay A (2008) Ascertaining The corporate objective: An entity maximisation and sustainability model. The Modern Law Review; 71 (5): 663-698.

Kerstein S (2002) Kant's Search for the Supreme Principle of Morality; New YorkCambridge University Press.

Koehn D (2005) Integrity as a business asset. Journal of Business Ethics; 58 (1): $125-136$
Kohlberg L (1981) The Philosophy of Moral Development Volumes I-III. Harper and Row: San Francisco, CA.

Korsgaard CM (1996) The Sources of Normativity. Cambridge University Press: Cambridge, UK

Lucas JR (1998) The responsibility of a businessman. In: Shaw WH (ed). Ethics at Work. Oxford University Press: New York, pp 59-79.

Marcoux AM (2003) A fiduciary argument against stakeholder theory. Business Ethics Quarterly; 13 (1): 1-24.

McFall L (1987) Integrity. Ethics; 98 (1): 5-20.

Nozick R (1974) Anarchy, State, and Utopia. Basic Books: Cambridge, MA

Orlitzky M (2015) The politics of corporate social responsibility or: Why milton friedman has been right all along. Annals in Social Responsibility; 1 (1): 5-29.

Orts E and Strudler A (2009) Putting a stake in stakeholder theory. Journal of Business Ethics; 88 (Supplement 4): 605-615.

Palanski ME and Yammarino FJ (2007) Integrity and leadership: Clearing the conceptual confusion. European Management Journal; 25 (3): 171-184.

Parry KW and Proctor-Thomson SB (2002) Perceived integrity of transformational leaders in organisational settings. Journal of Business Ethics; 35 (2): 75-96.

Pianalto M (2012) Integrity and struggle. Philosophia; 40 (2): 319-336.

Plender J (1997) A Stake in the Future: The Stakeholding Solution. Nicholas Brealey Publishing: London.

Rawls J (1955) Two concepts of rules. The Philosophical Review; 64 (1): 3-32.

Sidgwick H (1907) The Methods of Ethics, Indianapolis: Hacket, https://books. google.com/books?hl = en\&lr $=\& \mathrm{id}=$ YYYsGTuH8HYC\&oi $=$ fnd \&pg $=$ PA1\&dq $=$ sidgwick + methods + of + ethics\&ots $=\_$e $16 \mathrm{BbpPaO} \& \operatorname{sig}=\operatorname{mlrV} 4 \mathrm{q} 3 \mathrm{z}$ JeR8vZNY6KrNRxOAcQ, accessed 8 January 2016.

Simons T (2002) Behavioral integrity. The Perceived Alignment Between Managers Words and Deeds as a Research Focus; 13 (1): 18-35.

Smart JJC and Williams B (1973) Utilitarianism For and Against. Cambridge University Press: Cambridge, UK.

Solomon RC (1999) A Better Way to Think about Business: How personal integrity leads to corporate success. Oxford University Press: New York.

Stark A (1993) What's the matter with business? Harvard Business Review; 71 (3): $1-17$.

Sternberg E (1997) The defects of stakeholder theory. Corporate Governance; 5 (1): 3-10.

Sundaram AK and Inkpen AC (2004a) Stakeholder theory and " the corporate objective stakeholder theory and " the corporate objective revisited ": A reply. Organization Science; 15 (3): 370-371.

Sundaram AK and Inkpen AC (2004b) The corporate objective revisited Organization Science; 15 (3): 350-363.

Trevino LK, Hartman LP and Brown M (2000) Moral person and moral manager: How executives develop a reputation for ethical leadership. California Management Review; 42 (4): 128-143.

Vallance E (1995) Business Ethics at Work. Cambridge University Press: New York.

Venkataraman S (2002) Stakeholder value equilibriation and the entrepeneurial process. In: Freeman RE and Venkataraman S (eds). The Ruffin Series No. 3: Ethics and Entrepreneurship. Philosophy Documentation Center: Charlottesville, VA, pp. 45-57.

Williams B (1985) Ethics and the Limits of Philosophy, 1st ed., Harvard University Press: Cambridge, US

Winslow BJ and Winslow GR (1991) Integrity and compromise in nursing ethics The Journal of Medicine and Philosophy; 16 (3): 307-323.

Worden S (2003) The role of integrity as a mediator in strategic leadership: a recipe for reputational capital. Journal of Business Ethics; 46 (1): 31-44.

\section{Data availability}

Data availability not applicable to this article as no datasets were generated or analysed.

\section{Additional information}

Competing interests: The author(s) declare no competing financial interests.

Reprints and permission information is available at http://www.palgrave-journals.com/ pal/authors/rights_and_permissions.html

How to cite this article: Schwartz J (2016) Integrity: the virtue of compromise. Palgrave Communications. 2:16085 doi: 10.1057/palcomms.2016.85.

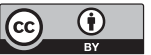

This work is licensed under a Creative Commons Attribution 4.0 International License. The images or other third party material in this article are included in the article's Creative Commons license, unless indicated otherwise in the credit line; if the material is not included under the Creative Commons license, users will need to obtain permission from the license holder to reproduce the material. To view a copy of this license, visit http://creativecommons.org/licenses/by/4.0/ 